\title{
Impact of mineral dust on nitrate, sulfate, and ozone in transpacific Asian pollution plumes
}

\author{
T. D. Fairlie ${ }^{1,2}$, D. J. Jacob ${ }^{2,3}$, J. E. Dibb ${ }^{4}$, B. Alexander ${ }^{5}$, M. A. Avery ${ }^{1}$, A. van Donkelaar ${ }^{6}$, and L. Zhang ${ }^{2}$ \\ ${ }^{1}$ NASA Langley Research Center, Hampton, VA 23681-0001, USA \\ ${ }^{2}$ Dept. Earth and Planetary Sciences, Harvard University, Cambridge, MA 02138, USA \\ ${ }^{3}$ Division of Engineering and Applied Science, Harvard University, Cambridge, MA 02138 USA \\ ${ }^{4}$ Climate Change Research Center, University of New Hampshire, Durham, NH 03824, USA \\ ${ }^{5}$ Dept. Atmospheric Sciences, University of Washington, Seattle, WA 98195, USA \\ ${ }^{6}$ Dept. Physics and Atmospheric Science, Dalhousie University, Halifax, Nova Scotia, B3H 4R2, Canada
}

Received: 18 October 2009 - Published in Atmos. Chem. Phys. Discuss.: 17 November 2009

Revised: 22 March 2010 - Accepted: 31 March 2010 - Published: 29 April 2010

\begin{abstract}
We use a 3-D global chemical transport model (GEOS-Chem) to interpret aircraft observations of nitrate and sulfate partitioning in transpacific dust plumes during the INTEX-B campaign of April-May 2006. The model includes explicit transport of size-resolved mineral dust and its alkalinity, nitrate, and sulfate content. The observations show that particulate nitrate is primarily associated with dust, sulfate is primarily associated with ammonium, and Asian dust remains alkaline across the Pacific. This can be reproduced in the model by using a reactive uptake coefficient for $\mathrm{HNO}_{3}$ on dust $\left(\gamma\left(\mathrm{HNO}_{3}\right) \sim 10^{-3}\right)$ much lower than commonly assumed in models and possibly reflecting limitation of uptake by dust dissolution. The model overestimates gasphase $\mathrm{HNO}_{3}$ by a factor of 2-3, typical of previous model studies; we show that this cannot be corrected by uptake on dust. We find that the fraction of aerosol nitrate on dust in the model increases from $\sim 30 \%$ in fresh Asian outflow to $80-90 \%$ over the Northeast Pacific, reflecting in part the volatilization of ammonium nitrate and the resulting transfer of nitrate to the dust. Consumption of dust alkalinity by uptake of acid gases in the model is slow relative to the lifetime of dust against deposition, so that dust does not acidify (at least not in the bulk). This limits the potential for dust iron released by acidification to become bio-available upon dust deposition. Observations in INTEX-B show no detectable
\end{abstract}

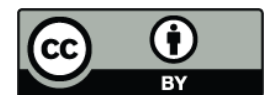

Correspondence to: T. D. Fairlie (t.d.fairlie@nasa.gov) ozone depletion in Asian dust plumes, consistent with the model. Uptake of $\mathrm{HNO}_{3}$ by dust, suppressing its recycling to $\mathrm{NO}_{\mathrm{x}}$, reduces Asian pollution influence on US surface ozone in the model by $10-15 \%$ or up to $1 \mathrm{ppb}$.

\section{Introduction}

Mineral dust is the largest single contributor to particulate matter in the atmosphere (Forster et al., 2008; Rind et al., 2009). Dust is mobilized to the atmosphere by strong surface winds over arid terrain (Ginoux et al., 2001; Prospero et al., 2002). Principal source regions in East Asia include the Gobi desert of Northern China and Mongolia, and the Taklimakan desert of western China (Prospero et al., 2002). Dust is an important air quality problem in the large population centers of Eastern China, Korea, and Japan, particularly in spring when dust storms are most active. Lofting to the free troposphere can result in long-range transport of Asian dust across the Pacific, impacting surface aerosol concentrations in North America (Jaffe et al., 1999; Husar et al., 2001; Szykman et al., 2003; Fairlie et al., 2007).

Dust particles can become coated with sulfate, nitrate, organic, and black carbon as they age in the atmosphere (Tabazadeh et al., 1998; Clarke et al., 2004; Jordan et al., 2003; Dibb et al., 2003; Kim et al., 2004; Ooki and Uematsu, 2005; Sullivan et al., 2007). Nitrate and sulfate form on dust through the uptake of acidic gases $\mathrm{HNO}_{3}, \mathrm{SO}_{2}$, and $\mathrm{H}_{2} \mathrm{SO}_{4}$

Published by Copernicus Publications on behalf of the European Geosciences Union. 
(Usher et al., 2003). Global and regional-scale modeling studies have shown significant consequences for sulfate and nitrate partitioning, tropospheric oxidants, and aerosol size distributions (Dentener et al., 1996; Song and Carmichael, 2001a, b; Liao et al., 2003; Bauer et al., 2004; Bauer and Koch, 2005; Hodzic et al., 2006; Shindell et al., 2007). Tabazadeh et al. (1998) suggested that uptake on dust could explain why many models overestimate $\mathrm{HNO}_{3}(\mathrm{~g})$ in the remote free troposphere (Chatfield et al., 1994; Thakur et al., 1999; Lawrence et al., 1999). Acidification of dust by uptake of sulfate could provide bio-available iron to the ocean surface (Meskhidze et al., 2005, and references therein). A shift of nitrate or sulfate towards larger particle sizes can change their direct radiative forcing characteristics (Liao and Seinfeld, 2005; Kim et al., 2004). In addition, coating of dust with soluble nitrate or sulfate can enhance its cloud condensation nuclei potential (Kelly et al., 2007), while reducing its ice nuclei efficiency (Koehler et al., 2007), with consequences for cloud properties and precipitation (Rosenfeld et al., 2001; Fan et al., 2004).

In this paper, we use a 3-D global chemical transport model (GEOS-Chem CTM) to investigate the effect of mineral dust on the chemical partitioning of total inorganic nitrate and sulfate over the Northeast Pacific during the spring 2006 INTEX-B airborne campaign (Singh et al., 2009). This campaign focused on intercontinental transport of pollution from Asia to North America. Dust outflow from East Asia was a pervasive feature. We consider flights of the NASA DC8 out of Honolulu, Hawaii, and Anchorage, Alaska (Regions 3 and 4 in Fig. 2a of Singh et al., 2009). We focus particularly on explaining observed particulate nitrate levels, ramifications for the lifetime of $\mathrm{HNO}_{3}(\mathrm{~g})$ with respect to uptake on dust, and whether dust can account for the high bias of $\mathrm{HNO}_{3}(\mathrm{~g})$ in models. Further, we use the model to describe the chemical ageing of mineral dust during transpacific transport from the Asian continent in terms of accumulation of nitrate and sulfate, titration of dust alkalinity, and impact on $\mathrm{NO}_{\mathrm{x}}$ and $\mathrm{O}_{3}$.

\section{GEOS-Chem model}

\subsection{General description}

The GEOS-Chem CTM was originally described by Bey et al. (2001). We use here version v8.01.01 (http://acmg.seas. havard.edu/geos/index.html). The model is driven by assimilated meteorological analyses from the Goddard Earth Observing System (GEOS-4) including 6-h average winds, temperatures, convective mass fluxes, and clouds, and 3-h average mixing depths and surface variables. These are available at $1^{\circ} \times 1.25^{\circ}$ horizontal resolution, and 48 vertical sigmapressure hybrid levels extending from the surface to $0.01 \mathrm{hPa}$. The horizontal resolution is degraded here to $2^{\circ} \times 2.5^{\circ}$ for input to GEOS-Chem.
The aerosol simulation in GEOS-Chem represents the sulfate-nitrate-ammonium system (Park et al., 2004), organic and black carbon (Park et al., 2003; Liao et al., 2007), sea salt (Alexander et al., 2005), and mineral dust (Fairlie et al., 2007), as an external mixture. The aerosol and gas phases are coupled through (1) aqueous-phase sulfur oxidation; (2) heterogeneous uptake of $\mathrm{NO}_{3}, \mathrm{NO}_{2}, \mathrm{~N}_{2} \mathrm{O}_{5}$, and $\mathrm{HO}_{2}$ (Jacob, 2000; Evans and Jacob, 2005); (3) aerosol effects on photolysis frequencies (Martin et al., 2003); and (4) gas-aerosol partitioning of total ammonia and inorganic nitrate, computed with the MARS-A thermodynamic model for the sulfate-ammonium-nitrate-water system (Binkowski and Roselle, 2003). MARS-A does not include mineral ion components; we treat the uptake of acidic gases by dust separately, and maintain fine dust-nitrate and dust-sulfate components distinct from the fine-mode sulfate-nitrate-ammonium system, as described below. Some thermodynamic models, e.g. ISORROPIA II (Fountoukis and Nenes, 2007) do include metal and chloride ions, but our results indicate that rapid equilibrium of $\mathrm{HNO}_{3}, \mathrm{SO}_{2}$, and bulk minerals is not appropriate, at least for coarse-mode dust.

Wet deposition is represented using the scheme of Liu et al. (2001), which accounts for scavenging by convective updrafts as well as rainout and washout. Dry deposition of gases and fine aerosol uses the resistance-in-series model of Wesely et al. (1989) as described by Wang et al. (1998). Dry deposition of dust and sea salt aerosols uses size-resolved calculations (Zhang et al., 2001), and accounts for gravitational settling (Seinfeld and Pandis, 1998).

GEOS-Chem has been used previously to show that Asian emissions can lead to enhanced concentrations of $\mathrm{CO}$, ozone, sulfate, and dust aerosols in North America (Heald et al., 2003; Jaegle et al., 2003; Hudman et al., 2004; Park et al., 2004; Heald et al., 2006; Park et al., 2006; Fairlie et al., 2007; Nam et al., 2009). The model has been applied previously to simulation of the INTEX-B data by Zhang et al. (2008), focusing on ozone, and by van Donkelaar et al. (2008), focusing on sulfate and organic aerosol. Here, we focus on the impact of dust on nitrate and sulfate partitioning in transpacific transport.

We use the same suite of emission inventories as Zhang et al. (2008) with the following exceptions. Global anthropogenic emissions of $\mathrm{NO}_{\mathrm{x}}, \mathrm{SO}_{\mathrm{x}}$ and $\mathrm{CO}$ are taken from the EDGAR 3.2FT2000 emission inventory based on the year 2000 (Olivier et al., 2001), instead of the Global Emission Inventory Activity (GEIA). We supplant the global inventory over Asia with an inventory for 2006 compiled by Zhang et al. (2009), which shows $65 \%$ higher emissions for $\mathrm{NO}_{\mathrm{x}}$, and $60 \%$ higher emissions for $\mathrm{SO}_{2}$ compared with the year 2000 .

\subsection{Mineral dust module}

Dust in GEOS-Chem is distributed in 4 size bins (radii 0.1$1.0,1.0-1.8,1.8-3.0$, and $3.0-6.0 \mu \mathrm{m}$ ), following Ginoux et al. (2004). The smallest size bin is further divided into 4 sub- 
bins (radii 0.1-0.18, 0.18-0.3, 0.3-0.6, 0.6-1.0 $\mu \mathrm{m}$ ) for optical properties and heterogeneous chemistry. We use the dust entrainment and deposition (DEAD) mobilization scheme of Zender et al. (2003), combined with the source function used in GOCART (Ginoux et al., 2001; Chin et al., 2004), as described by Fairlie et al. (2007), who used the model to study the impact of transpacific transport of dust on aerosol concentrations in the United States in 2001. Fairlie et al. (2007) found that the dust simulation captured the magnitude and seasonal cycle of dust over the Northeast Pacific, the timing and vertical structure of dust outflow in the free troposphere from Asia during the spring 2001 TRACE-P and ACE-Asia aircraft missions, and the timing and distribution of Asian dust outbreaks in the United States.

The dust simulations described by Fairlie et al. (2007) were driven by GEOS-3 meteorological analyses. Comparison of simulated dust emissions for spring 2001 using GEOS-3 and GEOS-4 fields indicates a doubling of dust emissions, both globally and from Asia, due to stronger surface winds in GEOS-4. Accordingly, we apply a factor of 2 reduction to the dust emissions computed from the GEOS-4 fields. Generoso et al. (2008) previously applied a factor of 3 reduction to the GEOS-Chem dust source computed from GEOS-4 winds in their study of Saharan dust outflow in 2006 and 2007. Our simulated global and Asian emissions for April-May 2006 are 287 and $25 \mathrm{Tg}$ respectively, compared to 321 and $33 \mathrm{Tg}$ for April-May 2001.

\subsection{Acid gas uptake on dust}

For this study we include in the model the reactive uptake of $\mathrm{HNO}_{3}$ and $\mathrm{SO}_{2}$ on dust, limited by dust alkalinity, and the uptake of gas-phase $\mathrm{H}_{2} \mathrm{SO}_{4}$ limited by competition with other aerosol surfaces. We exclude direct uptake of ozone on dust, because the DC8 data show no significant negative correlation of ozone and dust (see discussion below). Laboratory studies indicate that uptake of ozone on dust is slow and subject to surface passivation (Hanisch and Crowley, 2003; Mogili et al., 2006). We also neglect particle coagulation since most studies of Asian outflow indicate that urban and dust aerosols are largely externally mixed (Mori et al., 2003; Maxwell-Meier et al., 2004; Tang et al., 2004; Song et al., 2005).

Laboratory studies have shown that dust alkalinity, comprising carbonates and mineral oxides, enables reactive uptake of acidic gases $\mathrm{HNO}_{3}$ and $\mathrm{SO}_{2}$ (Usher et al., 2003, and references therein). Uptake of $\mathrm{HNO}_{3}$ takes place by acidbase titration on surface sites for dry dust, or in solution with adsorbed water (Goodman et al., 2000). Uptake of $\mathrm{SO}_{2}$ is thought to take place by aqueous-phase oxidation of $\mathrm{SO}_{3}^{2-}$ by $\mathrm{O}_{3}$ (Ullerstam et al., 2002). We use a standard first-order reactive uptake parameterization with rate constant $k_{i}$ to describe the loss of species $i$ from the gas phase, for dust radius size bin $[r 1, r 2]$ : $k_{i}=\int_{r_{1}}^{r_{2}} 4 \pi r^{2} N(r)\left(\frac{r}{D_{g}}+\frac{4}{v \gamma}\right)^{-1} d r$

Here $N(r)$ is the number density of dust particles of radius $[r, r+d r], D_{g}$ is the molecular diffusion coefficient (taken as $0.2 \mathrm{~cm}^{2} \mathrm{~s}^{-1}$ ), $v$ is the mean molecular speed (taken as $3.0 \times 10^{4} \mathrm{~cm} \mathrm{~s}^{-1}$ ), and $\gamma$ is the reactive uptake coefficient.

Previous model studies tend to lump dust into one or two size bins for gas-particle interactions (e.g., Song and Carmichael, 2001b; Liao et al., 2003; Solmon et al., 2009). Here, we compute the acid uptake separately for each dust size bin (plus the 4 sub-bins within the smallest size bin), and maintain dust nitrate, dust sulfate, and dust alkalinity as separate size-segregated constituents in the model. These constituents are subject to the same transport and deposition processes as the corresponding dust components.

Dust alkalinity is introduced in the model at the point of dust emission and is represented as the sum of calcium and magnesium carbonates, assuming that the $\mathrm{Ca}^{2+}$ and $\mathrm{Mg}^{2+}$ cation equivalents constitute 3.0 and $0.6 \%$ of the dust by mass, respectively. A 3\% estimate for soluble calcium lies in the range of estimates from observations near East Asian source regions (Claquin et al., 1999; Shi et al., 2005; Jeong, 2008) and is consistent with the estimate by McNaughton et al. (2008) for Asian dust sampled in INTEX-B. The $\mathrm{Ca}^{2+} / \mathrm{Mg}^{2+}$ ratio is obtained from the INTEX-B data. Dust alkalinity is consumed by the uptake of $\mathrm{HNO}_{3}, \mathrm{SO}_{2}$, and $\mathrm{H}_{2} \mathrm{SO}_{4}$; once the alkalinity is titrated the uptake of $\mathrm{HNO}_{3}$ and $\mathrm{SO}_{2}$ ceases.

Laboratory studies report a wide range of estimates for the reactive uptake coefficients $\gamma$ of acidic gases on calcite, mineral oxides, and real dust samples. Estimates for uptake on dry calcite range from $10^{-4}$ to 0.1 for $\gamma\left(\mathrm{HNO}_{3}\right.$ ) (Goodman et al., 2000; Hanisch and Crowley, 2001), and $10^{-4}$ to $4 \times 10^{-2}$ for $\gamma\left(\mathrm{SO}_{2}\right)$ (Usher et al., 2002; Ullerstam et al., 2003; Adams et al., 2005). Studies also show a marked increase in uptake rate with relative humidity for calcite, as uptake of water leads to enhanced ion mobility at the dust surface (Al-Hosney and Grassian, 2005; Vlasenko et al., 2006; Baltrusaitis et al., 2007a; Preszler-Prince et al., 2007; Liu et al., 2008). Uptake of $\mathrm{HNO}_{3}$ and $\mathrm{SO}_{2}$ on non-basic minerals is generally subject to surface saturation (Baltrusaitis et al., 2007b; Vlasenko et al., 2009).

Modeling studies have commonly used a constant value of 0.1 for $\gamma\left(\mathrm{HNO}_{3}\right)$ and a step function of relative humidity for $\gamma\left(\mathrm{SO}_{2}\right)\left(0.05-0.1\right.$ for $\mathrm{RH}>50 \%, 10^{-4}-10^{-2}$ for $\left.\mathrm{RH}<50 \%\right)$ (Dentener et al., 1996; Song and Carmichael, 2001a; Liao et al., 2003; Hodzik et al., 2006). We find here that such a high value of $\gamma\left(\mathrm{HNO}_{3}\right)$ greatly overestimates particulate nitrate formation in transpacific transport during INTEX-B, as described below. A Lagrangian model study of dust aging in Asian outflow by Song et al. (2007) similarly determined much smaller uptake coefficients $\gamma\left(\mathrm{HNO}_{3}\right)=5 . \times 10^{-3}$ and $\gamma\left(\mathrm{SO}_{2}\right)=1 . \times 10^{-4}$. A possible explanation is that only a fraction of the dust alkalinity is available for reaction at any 
time, and after initial saturation of reaction sites on the dust surface continued availability of alkalinity is limited by particle dissolution and diffusion. Fast initial uptake of $\mathrm{HNO}_{3}$ may thus not be sustainable for multi-day atmospheric transport.

Here, we use RH-dependent functions for $\gamma\left(\mathrm{HNO}_{3}\right)$ and $\gamma\left(\mathrm{SO}_{2}\right)$, as shown in Fig. 1. Peak values are of similar magnitude as those determined by Song et al. (2007). The RHdependences are based on recent laboratory results for uptake on calcite particles (Liu et al., 2008, for $\mathrm{HNO}_{3}$; PreszlerPrince et al., 2007, for $\mathrm{SO}_{2}$ ), and show the impact of the much lower deliquesce $\mathrm{RH}$ for reaction products $\mathrm{Ca}\left(\mathrm{NO}_{3}\right)_{2}$ (13-18\%), than for $\mathrm{CaSO}_{3}(\sim 90 \%)$ (Preszler-Prince et al., 2007). We represent uptake of $\mathrm{H}_{2} \mathrm{SO}_{4}(\mathrm{~g})$ on dust in competition with uptake by other aerosol components in the model, using a weighting proportional to surface area and mass transfer limitation (Eq. 1).

We conducted fully coupled GEOS-Chem simulations of oxidant and aerosol chemistry for the April-May 2006 INTEX-B period. Each simulation was initialized on 1 March 2006 using constituent fields from the previous INTEX-B model study by Zhang et al. (2008). Initial dust components were set to zero. Separate simulations were conducted with and without acid uptake by dust.

\subsection{Bulk aerosol and gas data}

Bulk aerosol, $\mathrm{HNO}_{3}$, and fine sulfate data shown here were obtained from the University of New Hampshire (UNH) Soluble Acidic Gases and Aerosol (SAGA) instruments on board the NASA DC8. Paired filter samples of bulk aerosol were collected with the UNH dual aerosol sampling probe, and analyzed for soluble ions including $\mathrm{NO}_{3}^{-}, \mathrm{SO}_{4}^{-}, \mathrm{NH}_{4}^{+}$, $\mathrm{Mg}^{2+}, \mathrm{Cl}^{-}, \mathrm{Na}^{+}, \mathrm{K}^{+}$, and $\mathrm{Ca}^{2+}$ (Dibb et al., 2003). Mean exposure times for the filters were $\sim 5-6 \mathrm{~min}$ for altitudes below $\sim 6 \mathrm{~km}$ and $10-14 \mathrm{~min}$ at higher altitudes. $\mathrm{HNO}_{3}$ and fine sulfate were measured in a mist chamber (Scheuer et al., 2003 ), with an aerosol size cut diameter of $\sim 1 \mu \mathrm{m}$; collection intervals were typically $2 \mathrm{~min}$ or less. Some contamination of the $\mathrm{HNO}_{3}$ measurement has been found in high $\mathrm{NH}_{4}\left(\mathrm{NO}_{3}\right)$ conditions, but no such artifact has been determined in high dust conditions. Ozone data shown here were obtained from the FASTOZ instrument at $1 \mathrm{~Hz}$ frequency.

\section{Transpacific transport of dust during INTEX-B}

Figure 2 shows model distributions of dust emission, $550 \mathrm{~nm}$ dust aerosol optical depth (AOD), and total AOD for the period 21 April-11 May 2006, spanning the bulk of INTEX-B flights over the Northeast Pacific. Also shown are satellite observations (MODIS) of $550 \mathrm{~nm}$ AOD for the same period. Model AOD at $550 \mathrm{~nm}$ is calculated as the sum of contributions from individual aerosol components with prescribed optical properties as a function of relative humidity (Martin

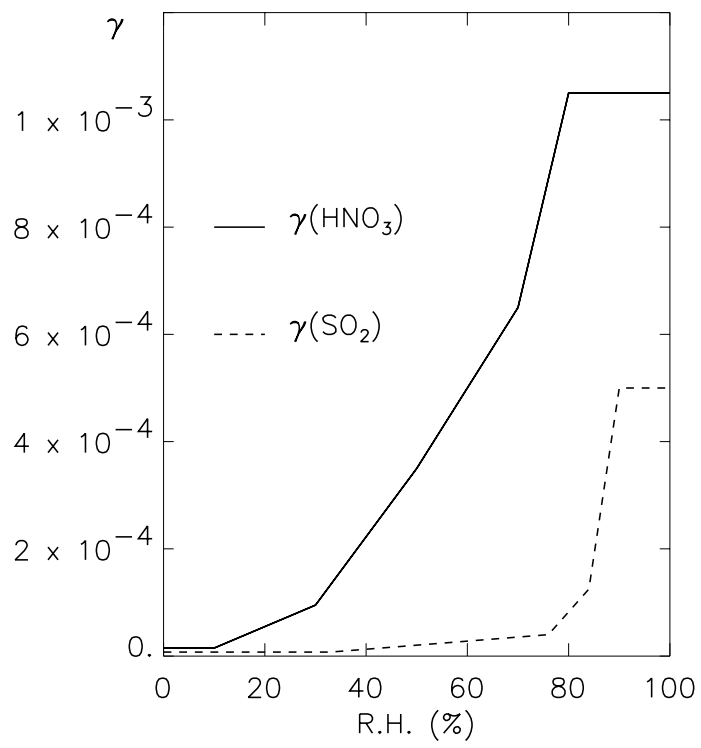

Fig. 1. Reactive uptake coefficients for $\mathrm{HNO}_{3}(\mathrm{~g})$ and $\mathrm{SO}_{2}(\mathrm{~g})$ on mineral dust used in this study as a function of relative humidity (RH).

et al., 2003) The Gobi and Taklimakan deserts of southern Mongolia and Western China were active dust sources during INTEX-B. The maps of simulated AOD illustrate the mean transpacific transport of dust and aerosol pollutants (principally sulfate; van Donkelaar et al., 2008) during INTEX-B. Flight tracks show that the DC-8 aircraft was well positioned to observe this transport. Van Donkelaar et al. (2008) show that GEOS-Chem captures many features of the day-to-day evolution in MODIS AOD associated with transpacific transport from Asia. We find that the model AOD is lower than MODIS, but this could reflect a MODIS high bias previously documented by comparison with island-based AOD observations from the AERONET network (Chin et al., 2004; Heald et al., 2006) and possibly reflecting the non-sphericity of dust (Chu et al., 2005). Van Donkelaar et al. (2008) show no such bias in their GEOS-Chem simulation compared to MODIS, but their dust emissions are not scaled for GEOS-4 winds and are thus twice ours (see Sect. 2.2).

Figure 3 shows the altitude distributions of observed vs. simulated $\mathrm{Ca}^{2+}$ concentrations for the INTEX-B flight tracks. Here and elsewhere we exclude observations made below $1 \mathrm{~km}$ (where sea salt complicates interpretation) or characteristic of the stratosphere $\left(\mathrm{O}_{3}>100 \mathrm{ppb}\right)$. We see from Fig. 3 that high dust concentrations extend through the $1-7 \mathrm{~km}$ column, with high variability, and drop rapidly above. Median model concentrations are about 50\% higher than observed. 


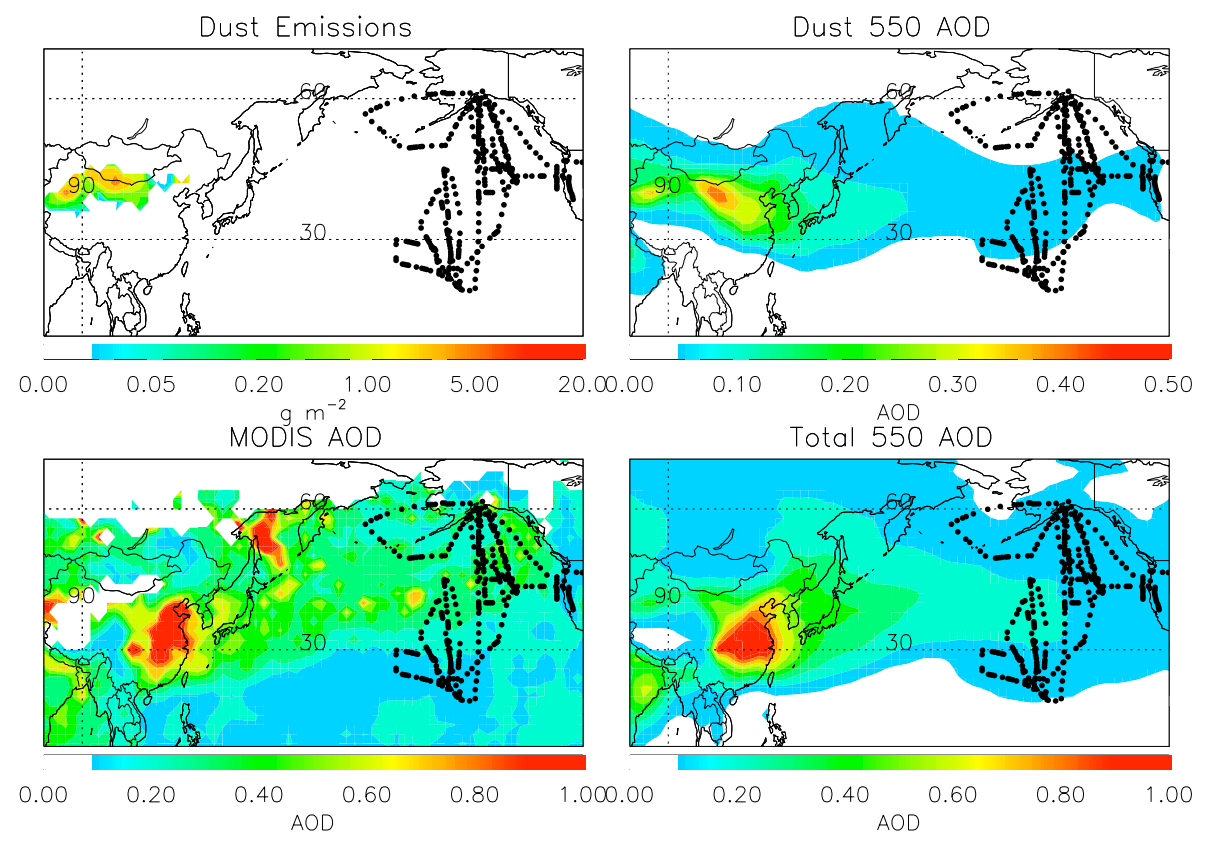

Fig. 2. Model distributions of dust emission (units: $\mathrm{g} \mathrm{m}^{-2}$ ), $550 \mathrm{~nm}$ dust aerosol optical depth (AOD), and total $550 \mathrm{~nm}$ AOD for the INTEXB period of 21 April-11 May 2006. The lower left panel shows the observed MODIS $550 \mathrm{~nm}$ AOD (Collection 5, Terra and Aqua satellites) for the same period. INTEX-B flight tracks are shown in black, with individual symbols denoting the aerosol samples used in this work.

\section{Partitioning of nitrate and sulfate}

Figure 4 shows various paired relationships of observed bulk $\mathrm{NO}_{3}^{-}, \mathrm{SO}_{4}^{2-}, \mathrm{NH}_{4}^{+}, \mathrm{Ca}^{2+}$ aerosol concentrations, and $\mathrm{HNO}_{3}(\mathrm{~g})$ concentrations, for the ensemble of INTEX-B data in Fig. 2. Model results without (Fig. 4a) and with (Fig. 4b) acid uptake by dust are also shown. The observations show a strong positive association of $\mathrm{NO}_{3}^{-}$and a weak negative association of $\mathrm{HNO}_{3}(\mathrm{~g})$ with mineral dust. The mean observed ratio of aerosol nitrate to total nitrate $\left(\mathrm{NO}_{3}^{-}+\mathrm{HNO}_{3}(\mathrm{~g})\right)$ increases from 0.4 for low dust to 0.7 for high dust conditions. Sulfate shows a weak positive association with dust, but a strong association with ammonium following the 1:2 ammonium sulfate relationship. The ratio of fine sulfate (from the SAGA mist chamber) to bulk sulfate mass $(\sim 0.7-0.9)$ indicates that the fine mode is dominant. The association of sulfate with $\mathrm{Ca}^{2+}$ may be explained by mixing of polluted and dust air streams in the Asian outflow (Clarke et al., 2001; Jordan et al., 2003; Heald et al., 2006). Panel (e) shows $\mathrm{NO}_{3}^{-}$vs. $\mathrm{NH}_{4}^{+}$after accounting for ammonium sulfate; little evidence is found for ammonium nitrate in the observations. This indicates that the aerosol nitrate is present in the dust particles, rather than merely coincident with them. Data points to the right of the 1-1 line in panel (e) show ammonium in excess of ammonium sulfate and ammonium nitrate combined. The physical explanation is not clear. No such data are found in the TRACE-P dataset, for example. Concentrations of $\mathrm{Cl}^{-}$ are too small for significant formation of $\mathrm{NH}_{4} \mathrm{Cl}$. There may be some positive bias in the $\mathrm{NH}_{4}^{+}$observations.

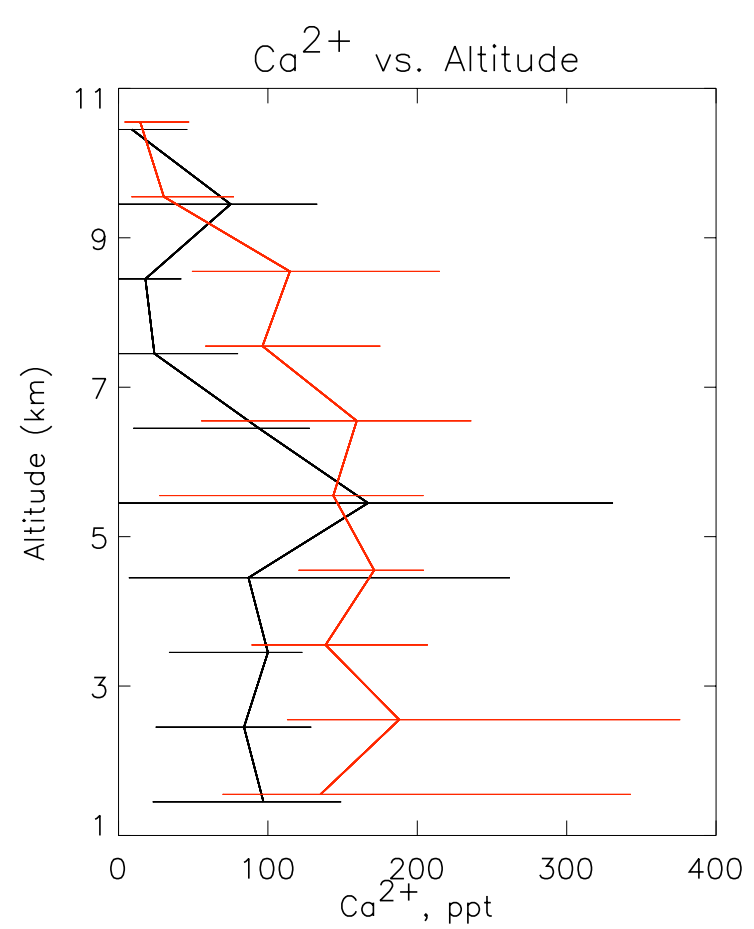

Fig. 3. Altitude distribution of observed (black) and simulated (red) $\mathrm{Ca}^{2+}$ concentrations during INTEX-B. The data are binned in $1 \mathrm{~km}$ vertical intervals. Profiles show median values in each bin. Whiskers span $50 \%$ of the data in each bin. 

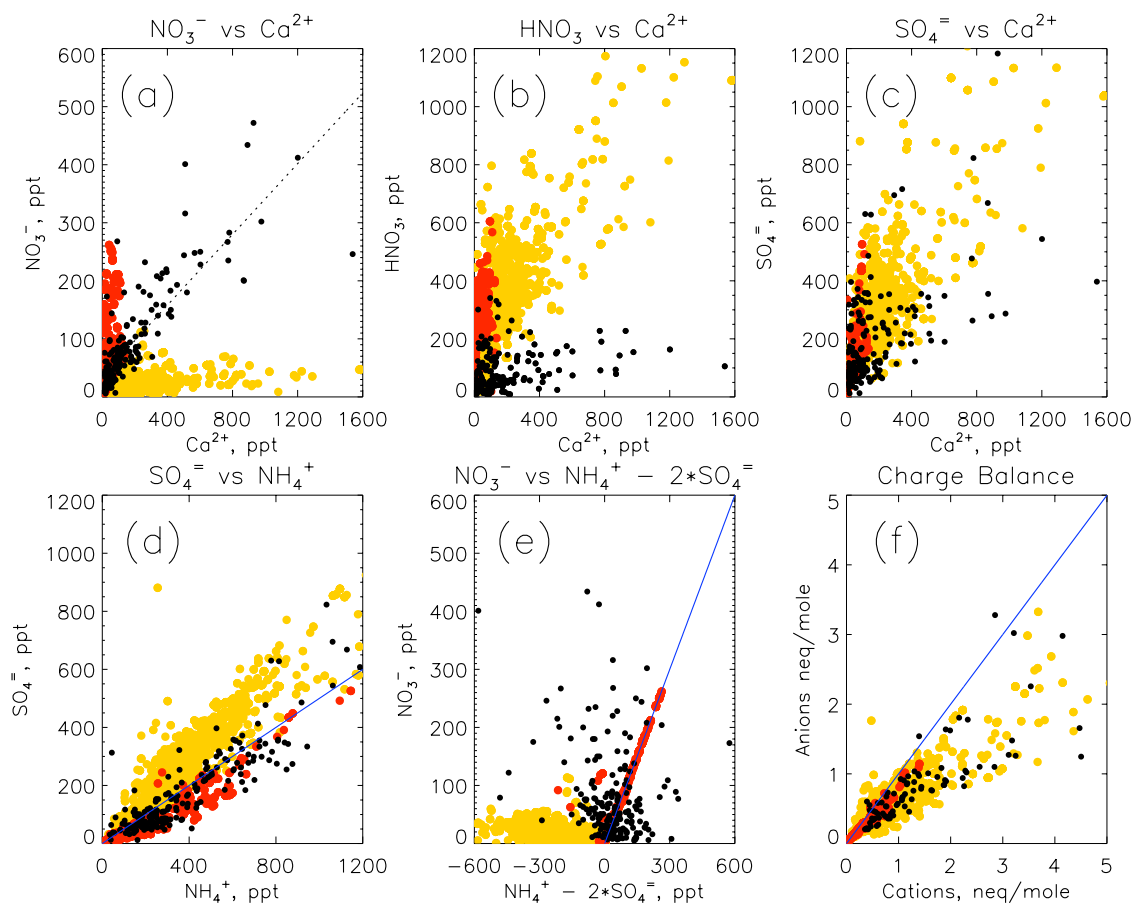

Fig. 4a. Relationships between bulk aerosol components and $\mathrm{HNO}_{3}(\mathrm{~g})$ concentrations along the INTEX-B flight tracks, excluding data below $1 \mathrm{~km}$ or in the stratosphere. Observations are shown in black, with each data point corresponding to an aerosol sample along the tracks shown in Fig. 2. Model values not including acid uptake by dust are shown in color, separately for dusty $\left(\left[\mathrm{Ca}^{2+}\right]>2\left[\mathrm{NO}_{3}^{-}\right] ;\right.$yellow) and non-dusty $\left(\left[\mathrm{Ca}^{2+}\right]<2\left[\mathrm{NO}_{3}^{-}\right]\right.$; red conditions. The bottom right panel shows the equivalent balance between the sum of measured cations $\left(\mathrm{Ca}^{2+}, \mathrm{Mg}^{2+}, \mathrm{K}^{+}, \mathrm{Na}^{+}, \mathrm{NH}_{4}^{+}\right)$and the sum of measured anions $\left(\mathrm{SO}_{4}^{2-}, \mathrm{NO}_{3}^{-}, \mathrm{Cl}^{-}\right)$. The black line in panel (a) shows the linear best fit to the observations; blue lines in panels (d), (e), and (f), show the 1:2, 1:1, and 1:1 relationships, respectively.

Panel (f) of Fig. 4a shows measured negative vs. positive equivalent charges in the bulk aerosol observations. The data show an anion deficit, which is positively correlated with $\mathrm{Ca}^{2+}$ (not shown), implying the presence of residual dust alkalinity at least in the bulk. In addition, the observations indicate that $\sim 100 \mathrm{ppt} \mathrm{HNO}_{3}(\mathrm{~g})$ coexists with the dust alkalinity (panel b). The dust plumes intercepted by the INTEXB aircraft were 3-7 days downstream of Asian source regions (H. Fuelberg, personal communication, 2008). The coexistence of significant $\mathrm{HNO}_{3}$ and dust alkalinity implies that the time scale for $\mathrm{HNO}_{3}$ uptake on dust must be on the order of days, consistent with the low $\gamma\left(\mathrm{HNO}_{3}\right)$ values used in this work, rather than hours as would result from $\gamma\left(\mathrm{HNO}_{3}\right) \sim 0.1$. The observed $\mathrm{HNO}_{3}$ values cannot be sustained by replenishment from $\mathrm{NO}_{\mathrm{x}}$ because observed $\mathrm{NO}_{\mathrm{x}}$ concentrations $(\sim 10-40 \mathrm{ppt})$ are too small. We note that the CIMS instrument on board the NSF C130 aircraft (Crounse et al., 2006) measures lower, yet significant, values of $\mathrm{HNO}_{3}(\mathrm{~g})(20-80 \mathrm{ppt})$ for dustiest conditions in the eastern Pacific during INTEX-B (J. Crounse, personal communication, 2010)

The model results without acid uptake by dust (Fig. 4a) show a striking difference with observations in the $\mathrm{NO}_{3}^{-}$vs. $\mathrm{Ca}^{2+}$ relationship. Simulated $\mathrm{NO}_{3}^{-}$vs. $\mathrm{Ca}^{2+}$ shows 2 distinct populations: one characterized by low $\mathrm{NO}_{3}^{-}(<\sim 100 \mathrm{ppt})$ (yellow points), the other characterized by low $\mathrm{Ca}^{2+}(<\sim$ $200 \mathrm{ppt}$ ) (red points). We refer to the former as the "dusty air stream," and the latter as the "low-dust air stream". In contrast with the observations, the model dusty air shows no correlation of dust with nitrate (panel a) and shows much higher $\mathrm{HNO}_{3}$ increasing with $\mathrm{Ca}^{2+}$ (panel b). It shows a weak positive relationship of $\mathrm{SO}_{4}^{2-}$ with $\mathrm{Ca}^{2+}$, similar to observations, further evidence that sulfate and dust are largely externally mixed. The charge balance plot (panel f) shows an anion deficit (residual alkalinity) in the model dusty air, comparable with observations. The low-dust population is much closer to charge balance (panel f).

Figure $4 \mathrm{~b}$ shows the model results with acid uptake by dust, using $\gamma\left(\mathrm{HNO}_{3}\right)$ and $\gamma\left(\mathrm{SO}_{2}\right)$ from Fig. 1. The dusty air stream in the model (yellow) shows an average six-fold increase of nitrate, bringing the model results closer to observations (panels a and e). The slope of the $\mathrm{NO}_{3}^{-}$vs. $\mathrm{Ca}^{2+}$ regression line for the dusty air stream (0.35) is comparable to the observations (0.31). Dust nitrate now accounts for $80-90 \%$ of aerosol nitrate in the dusty air, and $\mathrm{HNO}_{3}(\mathrm{~g})$ is reduced by $20-30 \%$. There is negligible change in total sulfate but the partitioning has changed; for the dusty air we now find $8-12 \%$ of the sulfate on dust. The sulfate fraction 

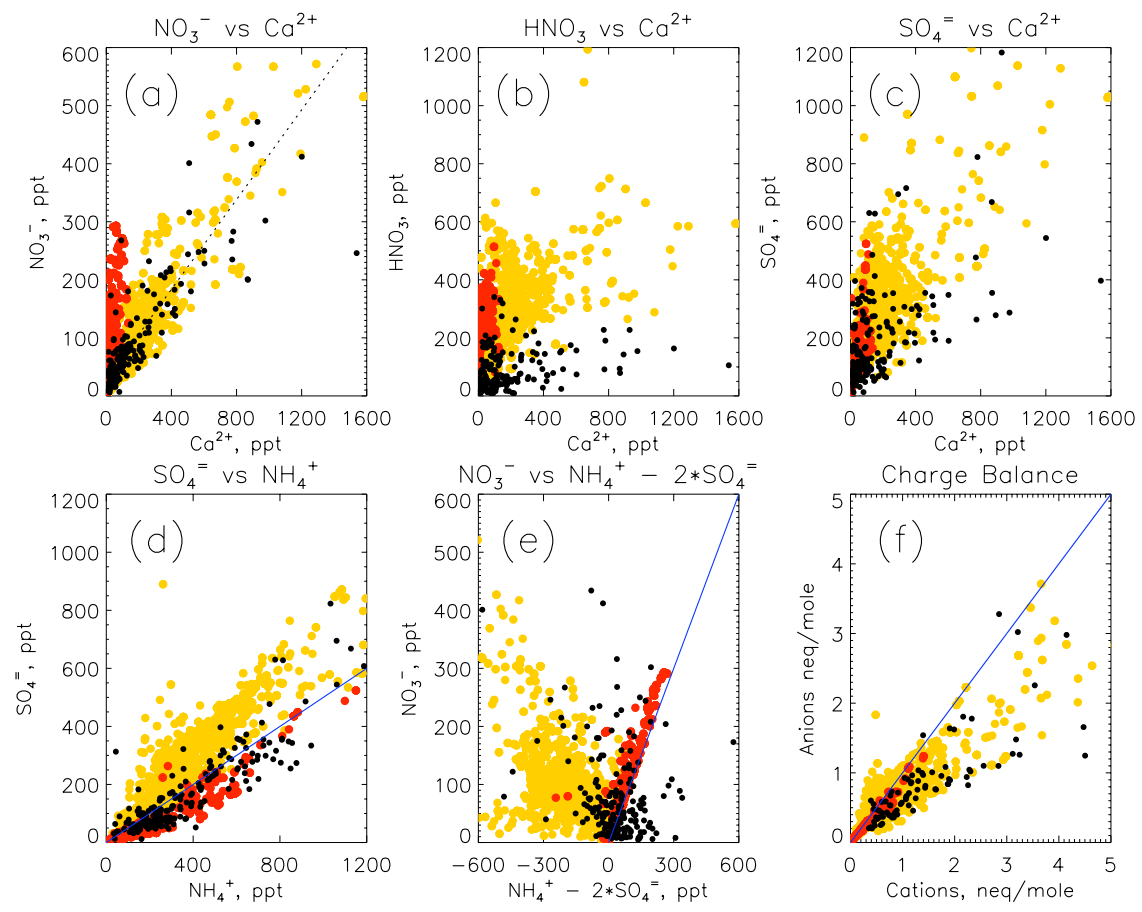

Fig. 4b. Same as Fig. 4a, but for the simulation including acid uptake on dust. The same colors mark the same points in both simulations. Black line in panel (a) is linear best fit to the model (yellow) results.

on dust is still small, comparable to observations. Uptake of $\mathrm{H}_{2} \mathrm{SO}_{4}$ accounts for $70-80 \%$ of the dust sulfate in the model, the rest is due to direct uptake of $\mathrm{SO}_{2}$. Acid uptake reduces model dust alkalinity by $20-25 \%$ (panel f) but does not titrate it, again consistent with observations.

The uptake of $\mathrm{HNO}_{3}(\mathrm{~g})$ on dust in the model still leaves $\mathrm{HNO}_{3}(\mathrm{~g})$ about 2-3 times too high, and the aerosol to total nitrate ratio $(\sim 0.5)$ is too low. We show in Fig. 5 that $\mathrm{HNO}_{3}(\mathrm{~g})$ in dusty air can be reduced to observed levels by increasing $\gamma\left(\mathrm{HNO}_{3}\right)$ by a factor of 10 , but this causes excessive aerosol nitrate. $\mathrm{HNO}_{3}(\mathrm{~g})$ can also be reduced by increasing dust surface area by scaling emissions (Sect. 2.2), but this causes excess nitrate and calcium. (Particulate nitrate and sulfate, and dust alkalinity consumption, respond quasilinearly to scaling of dust emissions because uptake rates depend linearly on dust surface area, Eq. 1). Furthermore, we find that the model high bias of $\mathrm{HNO}_{3}(\mathrm{~g})$ is present in both dusty and non-dusty conditions, and represents a general overestimate of total inorganic nitrate. Such an overestimate is a well-known problem of global tropospheric chemistry models (Chatfield et al., 1994; Thakur et al.,1999; Lawrence et al., 1999; Bey et al., 2001) and we see that it cannot be resolved by uptake of $\mathrm{HNO}_{3}(\mathrm{~g})$ on dust.

\section{Transpacific dust effects on nitrate, sulfate, and ozone}

Figure 6 shows maps of simulated dust and non-dust (ammonium) nitrate columns over the northern Pacific for the INTEX-B period. Dust nitrate accounts for $\sim 30 \%$ of aerosol nitrate over East Asia but 80-90\% over the Northeast Pacific. Dispersion and scavenging during Asian outflow and transpacific transport affect both dust and non-dust nitrate in a similar way, but ammonium nitrate drops far more sharply downwind of Asia due to volatilization as $\mathrm{NH}_{3}$ partial pressures fall. By contrast, production of dust nitrate is sustained across the Pacific from $\mathrm{HNO}_{3}(\mathrm{~g})$ produced both from oxidation of $\mathrm{NO}_{\mathrm{x}}$ and from ammonium nitrate volatilization. Previous model studies for Asian outflow using $\gamma\left(\mathrm{HNO}_{3}\right)=0.1$ report a larger fractionation of nitrate as dust (Dentener et al., 1996; Song and Carmichael, 2001b; Liao et al., 2003), but this appears inconsistent with the INTEX-B data as discussed above.

Figure 7 shows corresponding maps of dust and non-dust sulfate. In contrast to nitrate, the ratio of dust sulfate to total sulfate is small (8-10\%) over East Asia, falling to 5-8\% over the Northeast Pacific. Unlike ammonium nitrate, ammonium sulfate does not volatilize, and $\mathrm{SO}_{2}(\mathrm{~g})$ declines much more steeply than $\mathrm{HNO}_{3}(\mathrm{~g})$ off the coast, precluding significant sulfate production in transpacific transport. The decline in the dust to total sulfate ratio downstream can be explained by enhanced settling of the super-micron dust compared with fine sulfate. Previous model studies using a higher value for 

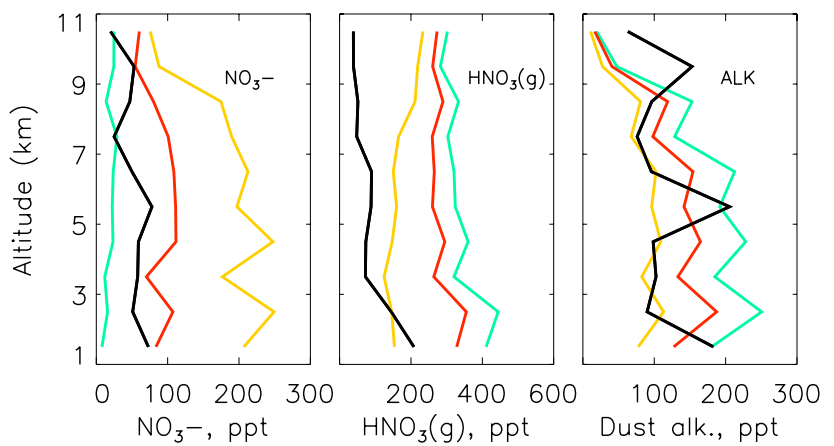

Fig. 5. Altitude profiles of observed (black) and simulated aerosol nitrate, $\mathrm{HNO}_{3}(\mathrm{~g})$, and dust alkalinity for the INTEX-B flights. Values are medians in 1-km vertical bins. Profiles are shown for the standard simulation with no acid uptake (green), the standard simulation with acid uptake (red), and a simulation with $\gamma\left(\mathrm{HNO}_{3}\right)$ increased by a factor of 10 from the values in Fig. 1 (yellow). Observed alkalinity is inferred from the anion deficit shown in Fig. 4.

$\gamma\left(\mathrm{SO}_{2}\right)$ show a much larger fractionation of sulfate as dust in Asian outflow and globally (Dentener et al., 1996; Song and Carmichael, 2001a; Liao et al., 2003), but this seems inconsistent with the low fraction of sulfate on dust apparent the INTEX-B data.

Dust alkalinity is regulated by the balance in supply between acids and bases, and by the time scales for alkalinity consumption vs. dust deposition. Simulated emissions of acid precursors from East Asia for April-May 2006 amount to $258 \mathrm{G}$ eq. ( $83 \mathrm{G}_{\text {moles }} \mathrm{SO}_{2}$ plus $92 \mathrm{G}_{\text {moles }} \mathrm{NO}_{\mathrm{x}}$ ), more than the combined alkaline emissions of $192 \mathrm{Geq}$. ( $142 \mathrm{G}$ moles $\mathrm{NH}_{3}$ plus $25 \mathrm{G}$ moles dust alkalinity). Yet, model results show only 20-25\% consumption of dust alkalinity across the Pacific. Only dust in the smallest size bin (radius $<1.0 \mu \mathrm{m}$ ) comes close to complete alkalinity titration (up to $\sim 90 \%$ locally, accounting for $60-70 \%$ of alkalinity consumption over the Pacific) due to its greater surface to volume ratio. The time scale for consumption of bulk dust alkalinity in transpacific transport in the model is 15-20 days, twice that for dust deposition. Thus the titration of dust is kinetically limited. Some studies indicate that the calcite content of the clay fraction of Asian dust is much smaller than for the bulk (Claquin et al., 1999; Shi et al., 2005). If we eliminate dust alkalinity from the smallest size bin, removing it as a sink for $\mathrm{HNO}_{3}$, we match the bulk consumption rate by increasing $\gamma\left(\mathrm{HNO}_{3}\right)$ by a factor of $2-3$.

Meskhidze et al. (2005) indicated that dust alkalinity must be titrated for the iron content to be soluble and bio-available upon deposition. They showed that calcite strongly buffers dust acidification in Asian outflow, limiting significant iron mobilization to dust plumes with high initial acid-to-dust ratios. Solmon et al. (2009) implemented the dust iron dissolution scheme of Meskhidze et al. (2005) in GEOS-Chem and predicted deposition of significant soluble iron during Asian
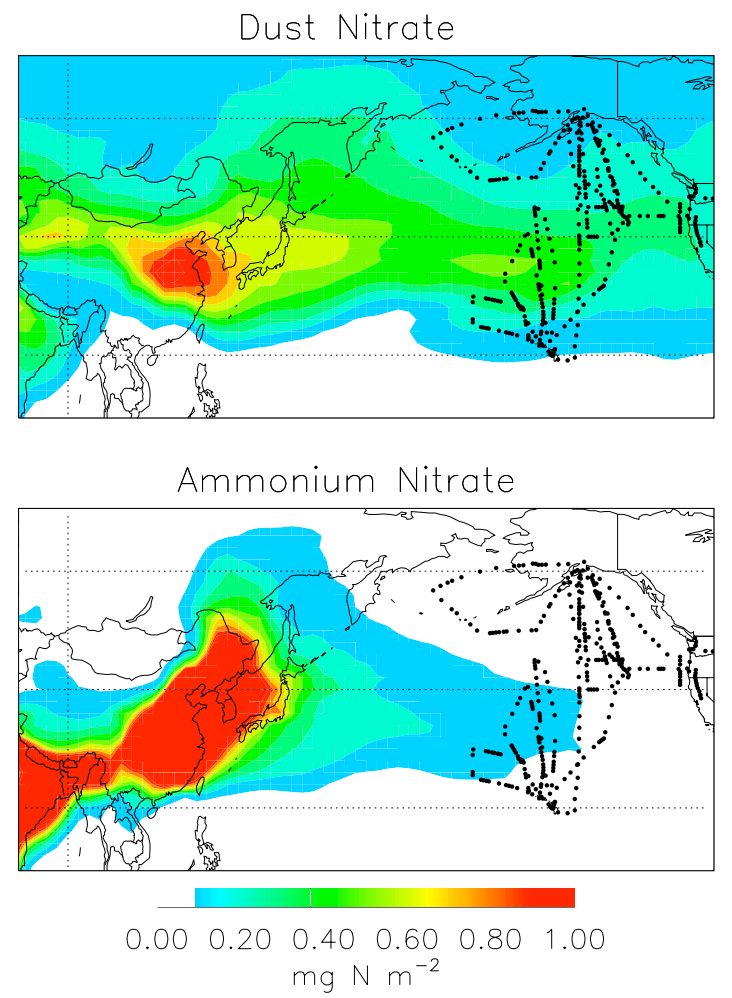

Fig. 6. Mean simulated column concentrations of dust nitrate and ammonium nitrate for the INTEX-B period (21 April-11 May 2006). Results are from the simulation including acid uptake. Black symbols show the aircraft flight tracks.

outflow in Spring 2001. They used a different scheme for acid uptake on dust than is used here. Notably, their assumed uptake rate for $\mathrm{SO}_{2}$ was 1-2 orders of magnitude larger than is obtained with $\gamma\left(\mathrm{SO}_{2}\right)$ in Eq. 1, leading to titration of dust alkalinity, which seems inconsistent with the INTEX-B observations. Our results indicate that iron mobilization may be limited to the smallest dust particles (radius $<1 \mu \mathrm{m}$ ) and to those with much lower initial alkalinity.

Figure 8 shows the observed and simulated relationship of ozone vs. $\mathrm{Ca}^{2+}$ at $4-6 \mathrm{~km}$ altitude. The observations show no apparent depletion of ozone in dust layers. In contrast, ozone reductions of up to $40 \%$ have been observed in Saharan dust outflow (DeReus et al., 2000; Umann et al., 2003; Bonasoni et al., 2004). DeReus et al. (2000) argued that direct uptake of ozone can explain about half of the depletion, while Umann et al. (2003) argued that it is due primarily to $\mathrm{HNO}_{3}$ uptake suppressing its recycling to $\mathrm{NO}_{\mathrm{x}}$. In our model, dust chemistry affects ozone only indirectly, via uptake of $\mathrm{HNO}_{3}$, as well as of $\mathrm{NO}_{3}, \mathrm{NO}_{2}, \mathrm{~N}_{2} \mathrm{O}_{5}$, and $\mathrm{HO}_{2}$. The effect is too small to cause any significant ozone depletion in dust plumes, and the simulated ozone vs. $\mathrm{Ca}^{2+}$ relationship in Fig. 8 is consistent with observations. It has, however, a non-negligible impact for Asian pollution influence on ozone air quality in North America, as ozone production 

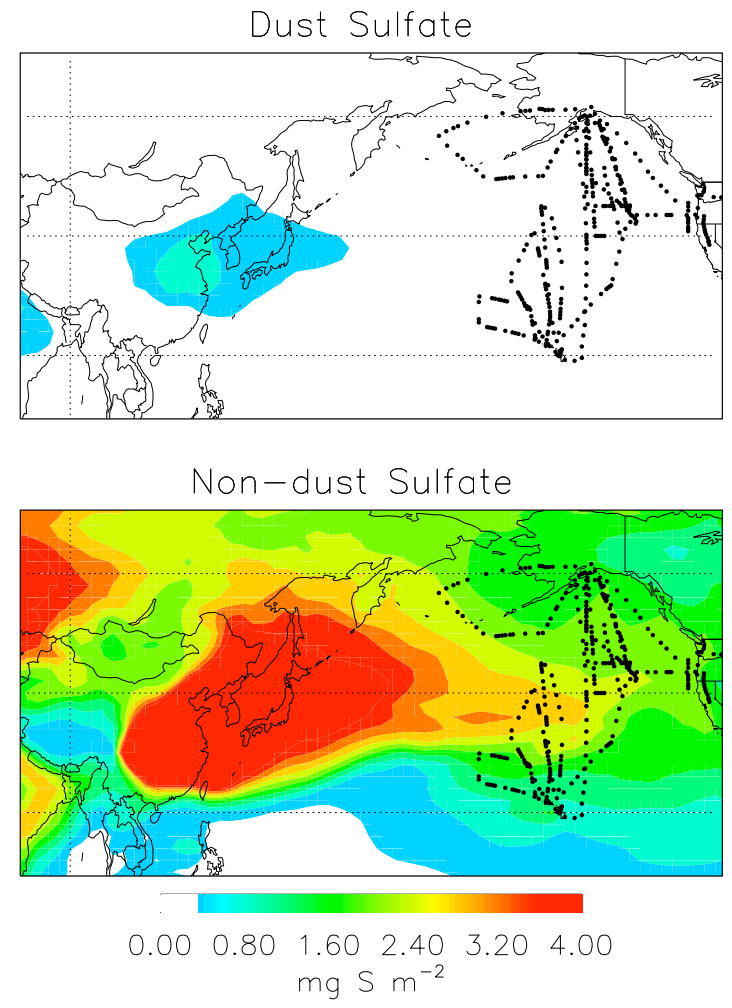

Fig. 7. As for Fig. 6, but for simulated dust and non-dust sulfate.

over the eastern Pacific from chemically recycled $\mathrm{NO}_{\mathrm{x}}$ is an important driver for this influence (Kotchenruther et al., 2001; Heald et al., 2003; Hudman et al., 2004; Zhang et al., 2008). Figure 9 shows the mean simulated changes in the northern Pacific tropospheric ozone column and the surface ozone concentrations over North America for the INTEX-B period due to $\mathrm{HNO}_{3}$ uptake by dust. Column ozone is reduced by up to 1 DU ( $\sim 2 \%)$ over the Northeast Pacific, and surface ozone over North America shows mean reductions of up to $1 \mathrm{ppb}$. Zhang et al. (2008) previously found that Asian anthropogenic sources increased surface ozone over the western United States by 5-7 ppb during the INTEX-B period. We find here that $\mathrm{HNO}_{3}$ uptake by dust decreases this Asian influence by $10-15 \%$.

Use of a higher uptake coefficient for $\gamma\left(\mathrm{HNO}_{3}\right)$ increases the impact on ozone in the model. We find $\sim 5 \%$ reductions in column ozone over the Northern Pacific and up to $4 \mathrm{ppb}$ reductions in surface ozone over North America when we multiply $\gamma\left(\mathrm{HNO}_{3}\right)$ by a factor of 10 . However, this results in a low bias compared with the ozone observations shown in Fig. 8 and nitrate levels inconsistent with the INTEX-B data (Fig. 5). Models that use higher uptake rates for $\mathrm{HNO}_{3}$ on dust may overestimate the impact of dust on ozone.

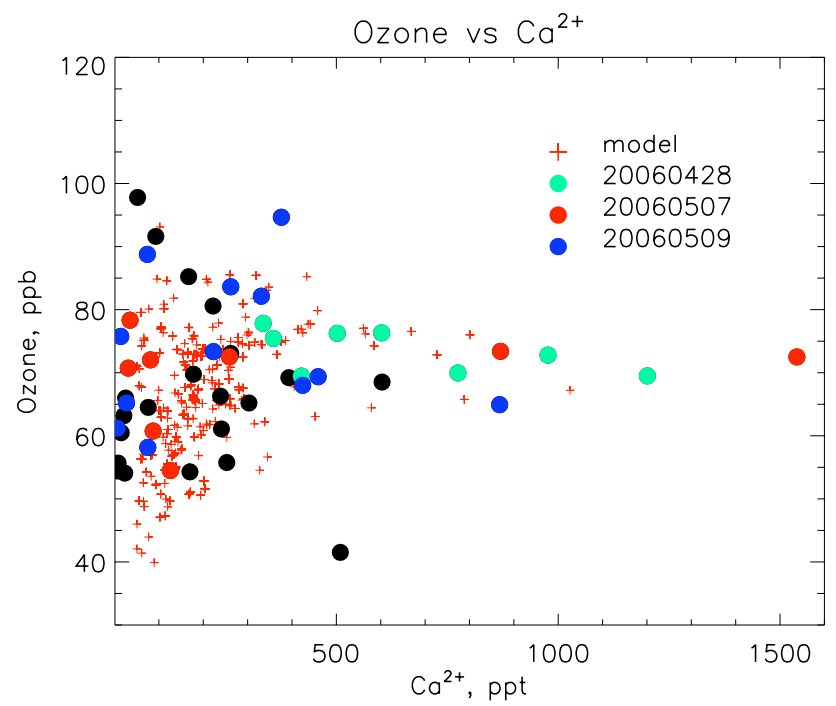

Fig. 8. Relationship between observed ozone and $\mathrm{Ca}^{2+}$ concentrations at 4-6 km altitude for the INTEX-B flights (filled circles). Observations on days with a large range of $\mathrm{Ca}^{2+}$ are colored. Corresponding model results are also shown (red crosses); low $\mathrm{Ca}^{2+}$ $(<50 \mathrm{ppt})$ points are excluded for clarity.
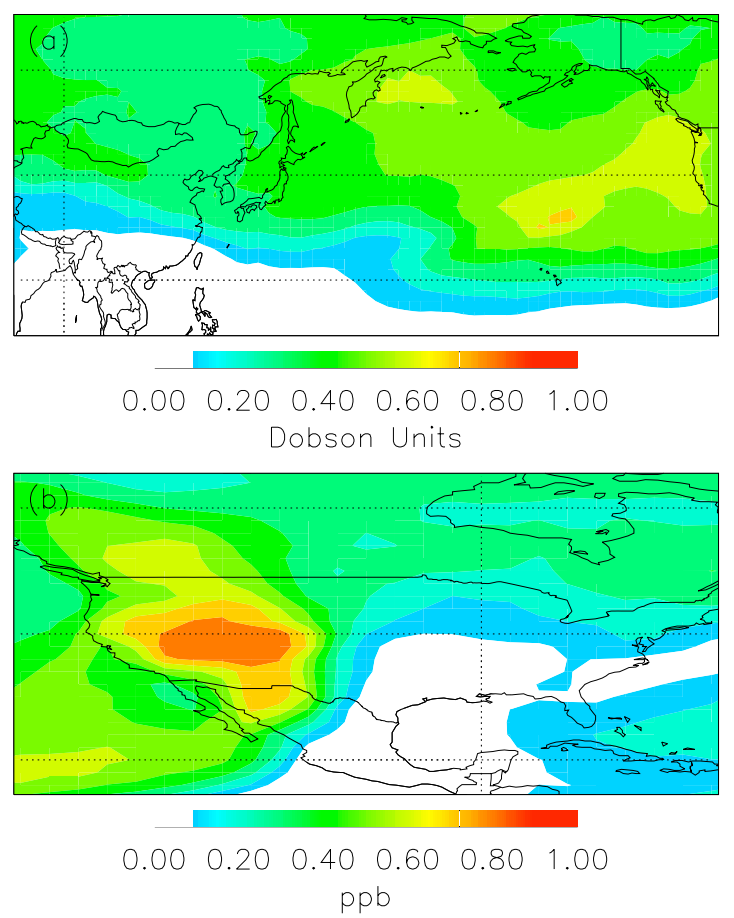

Fig. 9. Effect of $\mathrm{HNO}_{3}$ uptake by dust on (a) tropospheric ozone columns over the Pacific, and (b) surface ozone over North America. Values are mean differences for the INTEX-B period (21 April11 May 2006) between simulations conducted with vs. without uptake of acids on dust. 


\section{Conclusions}

We have used a 3-D global chemical transport model (GEOSChem) to interpret aircraft aerosol observations over the Northeast Pacific (INTEX-B campaign) in terms of nitrate and sulfate uptake on dust during transpacific transport, and implications for ozone. The model includes explicit transport of dust alkalinity as a limiting factor for $\mathrm{HNO}_{3}$ and $\mathrm{SO}_{2}$ uptake, and dust uptake of $\mathrm{H}_{2} \mathrm{SO}_{4}$ in competition with other aerosol surfaces.

Active dust sources in the Gobi and Taklimakan regions of China and Mongolia were a major source of transpacific dust during INTEX-B. The aircraft observations and the model show a strong positive association of particulate nitrate with dust, a weaker positive association of sulfate, and a weak negative association of $\mathrm{HNO}_{3}(\mathrm{~g})$. We show that nitrate is mainly present in the dust while sulfate is principally present as ammonium sulfate, its association with dust mostly reflecting common transport. The observations also indicate that dust remains alkaline over the Northeast Pacific, at least in the bulk, even after 3-7 days of transpacific transport.

We show that uptake of $\mathrm{HNO}_{3}$ on dust in the model can reproduce the observed relationship between particulate nitrate and calcium as well as the observed residual alkalinity. However, this requires that the rate of uptake of $\mathrm{HNO}_{3}$ by dust be relatively slow, represented in the model by a reactive uptake coefficient $\gamma\left(\mathrm{HNO}_{3}\right) \sim 1 \times 10^{-3}$. Previous models have generally assumed $\gamma\left(\mathrm{HNO}_{3}\right) \sim 0.1$, but we find that this results in excess nitrate on dust and insufficient dust alkalinity relative to the INTEX-B observations. A much lower value for $\gamma\left(\mathrm{HNO}_{3}\right)$ is needed to explain the coexistence of significant $\mathrm{HNO}_{3}(\sim 100 \mathrm{ppt})$ with dust alkalinity in the aircraft observations, which may reflect limitation of $\mathrm{HNO}_{3}$ uptake by dust dissolution.

Simulated $\mathrm{HNO}_{3}(\mathrm{~g})$ concentrations are 2-3 times higher than observed. Such an overestimate of $\mathrm{HNO}_{3}$ in the remote atmosphere has been a long-standing problem for global models. Uptake by dust has previously been proposed as a solution but we do not find this solution satisfactory. The model overestimate is similar for dusty and non-dusty conditions, and increased uptake of $\mathrm{HNO}_{3}$ by the dust results in a large overestimate of observed dust nitrate.

We find that the fraction of nitrate on dust in the model increases from $25-30 \%$ in fresh Asian outflow to $80-90 \%$ across the Pacific, partly reflecting the transfer from ammonium nitrate to dust nitrate through the volatilization of ammonia. By contrast, the fraction of sulfate on dust (mostly from uptake of $\mathrm{H}_{2} \mathrm{SO}_{4}$, with a small contribution from direct uptake of $\mathrm{SO}_{2}$ ) decreases from 8-12\% in fresh Asian outflow to $5-8 \%$ across the Pacific. This reflects the lack of sustained sulfate production over the Pacific.

The model shows $20-25 \%$ consumption of bulk dust alkalinity due to acid uptake by the time that Asian dust has reached the Northeast Pacific, consistent with the INTEXB observations. Dust alkalinity is in general never titrated in the model. This reflects a longer atmospheric time scale for dust alkalinity consumption (15-20 days) than for dust deposition (7-9 days), and argues against the possibility of bulk dust acidification releasing bio-available iron upon deposition to the oceans. Individual dust particles could still be titrated, either because of small size or low initial alkalinity.

Observations in INTEX-B show no detectable depletion of ozone in dust plumes, arguing against direct uptake of ozone by dust. We find in the model that uptake of $\mathrm{HNO}_{3}$, suppressing gas-phase recycling to $\mathrm{NO}_{\mathrm{x}}$, is too slow to deplete ozone significantly in dust plumes, consistent with observations. However, it still decreases the impact of Asian pollution on surface ozone in the United States by $10-15 \%$, or up to $1 \mathrm{ppb}$ in the West.

Acknowledgements. This work was funded by the NASA Global Tropospheric Chemistry Program, the NASA Langley Research Center Science Directorate, and the Advanced Study Program. Thanks to the following colleagues for discussions in the course of this work: M. Ammann, B. Anderson, J. Baltrusaitis, G. Chen, J. Crawford, J. Crounse, B. Doddridge, V. Grassian, C. Jordan, C. Kittaka, A. Laskin, H. Liu, C. McNaughton, R. Martin, S. Martin, N. Meskhidze, J. Olson, R. Park, E. Scheuer, Z. Shi, F. Solmon, C. Song, P. Wennberg. Thanks to the two anonymous reviewers for their comments.

Edited by: H. Singh

\section{References}

Adams, J. W., Rodriguez, D., and Cox, R. A.: The uptake of $\mathrm{SO}_{2}$ on Saharan dust: a flow tube study, Atmos. Chem. Phys., 5, 2679 2689, 2005, http://www.atmos-chem-phys.net/5/2679/2005/.

Adams, P. J., Seinfeld, J. H., and Koch, D. M.: Global concentrations of tropospheric sulfate, nitrate, and ammonium aerosol simulated in a general circulation model, J. Geophys. Res. 104(D11), 13791-13823, 1999.

Alexander, B., Park, R. J., Jacob, D. J., Li, Q. B., Yantosca, R. M., Savarino, J., Lee, C. C. W., and Thiemens, M. H.: Sulfate formation in sea-salt aerosols: Constraints from oxygen isotopes, J. Geophys. Res., 110, D10307, doi:10.1029/2004JD005659, 2005.

Al-Hosney, H. A. and Grassian, V. H.: Water, sulfur dioxide and nitric acid adsorption on calcium carbonate: A transmission and ATR-FTIR study, Phys . Chem. Chem. Phys., 7, 1266-1276, 2005

Baltrusaitis, J., Usher, C. R., and Grassian, V. H.: Reactions of sulfur dioxide on calcium carbonate single crystal and particle surfaces at the adsorbed water carbonate interface, Phys. Chem. Chem. Phys., 9, 3011-3024, 2007a.

Baltrusaitis, J., Cwiertny, D. M., and Grassian, V. H.: Adsorption of sulfur dioxide on hematite and goethite particle surfaces, Phys. Chem. Chem. Phys., 9, 5542-5554, 2007b.

Bauer, S. E., Balkanski, Y. J., Schulz, M., and Hauglustaine, D. A.: Global modeling of heterogeneous chemistry on mineral aerosol surfaces: Influence on tropospheric ozone chemistry and comparison to observations, J. Geophys. Res., 109, D02304, doi:10.1029/2003JD003868, 2004. 
Bauer, S. E. and Koch, D.: Impact of heterogeneous sulfate formation at mineral dust surfaces on aerosol loads and radiative forcing in the Goddard Institute for Space Studies general circulation model, J. Geophys. Res. 110, D17202, doi:10.1029/2005JD005870, 2005.

Bey, I., Jacob, D. J., Yantosca, R. M., et al.: Global modeling of tropospheric chemistry with assimilated meteorology: Model description and evaluation, J. Geophys. Res., 106(D19), 2307323096, 2001.

Binkowski, F. S. and Roselle, S. J.: Models-3 Community Multiscale Air Quality (CMAQ) model aerosol component, 1, Model description, J. Geophys. Res., 108(D6), 4183, doi:10.1029/2001JD001409, 2003.

Chatfield, R. B.: Anomalous $\mathrm{HNO} / \mathrm{NO}_{\mathrm{x}}$ ratio of remote troposheric air: Conversion of nitric acid to formic acid and $\mathrm{NO}_{\mathrm{x}}$ ?, Geophys. Res. Lett., 21, 2705-2708, 1994.

Chin, M., Chu, A., Levy, R., Remer, L., Kaufman, Y., Holben, B., Eck, T., Ginoux, P., and Gao, O.: Aerosol distribution in the Northern Hemisphere during ACE-Asia: Results from global model, satellite observations, and Sun photometer measurements, J. Geophys. Res., 109, D23S90, doi:10.1029/2004JD004829, 2004.

Chu, D. A., Remer, L. A., Kaufman, Y. J., et al.: Evaluation of aerosol properties over ocean from Moderate Resolution Imaging Spectroradiometer (MODIS) during ACE-Asia, J. Geophys. Res., 110, D07308, doi:10.1029/2004JD005208, 2005.

Claquin, T., Schulz, M., and Balkanski, Y. J.: Modeling the mineralogy of atmospheric dust sources, J. Geophys. Res., 104(D18), 22243-22256, 1999.

Clarke, A. D., Shinozuka, Y., Kapustin, V. N., et al.: Size distributions and mixtures of dust and black carbon aerosol in Asian outflow: Physiochemistry and optical properties, J. Geophys. Res., 109, D15S09, doi:10.1029/2003JD004378, 2004.

Crounse, J. D., McKinney, K. A., Kwan, A. J., and Wennberg, P. O.: Measurement of gas-phase hydroperoxides by chemical ionization mass spectrometry (CIMS), Anal. Chem., 78, 6726-6732, 2006.

Dentener, F. J., Carmichael, G. R., Zhang, Y., Lelieveld, J., and Crutzen, P.J.: Role of mineral aerosol as a reactive surface in the global troposphere, J. Geophys. Res., 101(D17), 22869-22889, 1996.

Dibb, J. E., Talbot, R. W., Scheuer, E. M., et al.: Aerosol chemical composition in Asian continental outflow during TRACE-P: comparison to PEM-West B, J. Geophys. Res. 108(D21), 8815, doi:10.1029/2002JD003111, 2003.

Duncan, B. N., Martin, R. V., Staudt, A. C., Yevich, R., and Logan, J. A.: Interannual and seasonal variability of biomass burning emissions constrained by satellite observations, J. Geophys. Res. 108(D2), 4040, doi:10.1029/2002JD002378, 2003.

Evans, M. J. and Jacob, D. J.: Impact of new laboratory studies of N2O5 hydrolysis on global model budgets of tropospheric nitrogen oxides, ozone, and $\mathrm{OH}$, Geophys. Res. Lett., 32, L09813, doi:10.1029/2005GL022469, 2005.

Fairlie, T. D., Jacob, D. J., and Park, R. J.: The impact of transpacific transport of mineral dust in the United States, Atmos. Environ., 41, 1251-1266, 2007.

Fan, S.-M., Horowitz, L. W. , Levy II, H., and Moxim, W. J.: Impact of air pollution on wet deposition of mineral dust aerosols, Geophys. Res. Lett., 31, L02104, doi:10.1029/2003GL018501,
2004.

Fountoukis, C. and Nenes, A.: ISORROPIA II: a computationally efficient thermodynamic equilibrium model for $\mathrm{K}^{+} \mathrm{Ca}^{2+} \mathrm{Mg}^{2+} \mathrm{NH}_{4}^{+} \mathrm{Na}^{+} \mathrm{SO}_{4}^{2-} \mathrm{NO}_{3}^{-} \mathrm{Cl}^{-} \mathrm{H}_{2} \mathrm{O}$ aerosols, Atmos. Chem. Phys., 7, 4639-4659, 2007,

http://www.atmos-chem-phys.net/7/4639/2007/.

Forster, P., Artaxo, P., Berntsen, T., Betts, R., et al.: Changes in Atmospheric Constituents and in Radiative Forcing. In: Climate Change 2007: The Physical Science Basis. Contribution of Working Group I to the Fourth Assessment Report of the Intergovernmental Panel on Climate Change, edited by: Solomon, S., Qin, D., Manning, M., Chen, Z., Marquis, M., Avert, K. B., Tignor, M., and Miller, H. L., Cambridge University Press, Cambridge, United Kingdom and New York, NY, USA, 2007.

Generoso, S., Bey, I., Labonne, M., and Bre'on F.-M.: Aerosol vertical distribution in dust outflow over the Atlantic: Comparisons between GEOS-Chem and Cloud-Aerosol Lidar and Infrared Pathfinder Satellite Observation (CALIPSO), J. Geophys. Res., 113, D24209, doi:10.1029/2008JD010154, 2008.

Ginoux, P., Chin, M., Tegen, I., et al.: Sources and distributions of dust aerosols simulated with the GOCART model, J. Geophys. Res., 106(D17), 20255-20274, 2001.

Ginoux, P., Prospero, J. M., Torres, O., and Chin, M.: Long-term simulation of global dust distribution with the GOCART model: correlation with North Atlantic Oscillation, Environ. Modell. Softw., 19, 113-128, 2004.

Goodman, A. L., Underwood, G. M., and Grassian, V. H.: A laboratory study of the heterogeneous reaction of nitric acid on calcium carbonate particles, J. Geophys. Res., 105(D23), 29053-29064, 2000.

Grassian, V. H.: Chemical Reactions of Nitrogen Oxides on the Surface of Oxide, Carbonate, Soot, and Mineral Dust Particles: Implications for the Chemical Balance of the Troposphere, J. Phys. Chem. A, 106, 860-877, 2002.

Hanisch, F. and Crowley, J. N.: The heterogeneous reactivity of gaseous nitric acid on authentic mineral dust samples, and on individual mineral and clay mineral components, Phys. Chem. Chem. Phys., 3, 2474-2482, 2001.

Hanisch, F. and Crowley, J. N.: Ozone decomposition on Saharan dust: an experimental investigation, Atmos. Chem. Phys., 3, 119-130, 2003, http://www.atmos-chem-phys.net/3/119/2003/.

Heald, C. L., Jacob, D. J., Fiore, A. M., et al.: Asian outflow and transpacific transport of carbon monoxide and ozone pollution, J. Geophys. Res., 108(D24), 4804, doi:10.1029/2003JD003507, 2003.

Heald, C. L., Jacob, D. J., Park, R. J., et al.: Transpacific transport of Asian anthropogenic aerosols and its impact on surface air quality in the United States, J. Geophys. Res., D14310, doi:10.1029/2005JD006847, 2006.

Hodzic, A., Bessagnet, B., and Vautard, R.: A model evaluation of coarse-mode nitrate heterogeneous formation on dust particles, Atmos. Environ., 40 4158-4171, 2006.

Hudman, R. C., Jacob, D. J., Cooper, O. R., et al.: Ozone production in transpacific Asian pollution plumes and implications for ozone air quality in California, J. Geophys. Res., 109, D23S10, doi:10.1029/2004JD004974, 2004.

Husar, R., Tratt, D. M., Schichtel, B. A., et al.: Asian dust events of April, 1998, J. Geophys. Res., 106(D16), 18317-18330, 2001. 
Jeong, G.-Y.: Bulk and single-particle mineralogy of Asian dust and a comparison with its source soils, J. Geophys. Res., 113, D02208, doi:10.1029/2007JD008606, 2008.

Jacob, D. J.: Heterogeneous chemistry and tropospheric ozone, Atmos. Environ., 34, 2131-2159, 2000.

Jaegle, L., Jaffe, D. A., Price, H. U., et al.: Sources and budgets for $\mathrm{CO}$ and ozone in the northeastern Pacific during the spring of 2001: results from the PHOBEA -II experiment, J. Geophys. Res., 108(D20), 8802, doi:10.1020/2002JD003121, 2003.

Jaffe, D., Anderson, T., Covert, D., et al.: Transport of Asian air pollution to North America, Geophys. Res. Lett., 26(6), 711714, 1999.

Jordan, C. E., Dibb, J. E., Anderson, B. E., and Fuelberg, H. E.: Uptake of nitrate and sulfate on dust aerosols during TRACE-P, J. Geophys. Res., 108(D21), 8817, doi:10.1029/2002JD003101, 2003.

Kelly, J. T., Chuang, C. C., and Wexler, A. S.: Influence of dust composition on cloud droplet formation, Atmos. Environ., 41, 2904-2916, 2007.

Kim, K. W., Zhuanshi, H., and Kim, Y. J.: Physicochemical characteristics and radiative properties of Asian dust, J. Geophys. Res., 109, D19S02, doi:10.1029/2003JD003693, 2004.

Kotchenruther, R. A., Jaffe, D. A., and Jaeglé, L.: Ozone photochemistry and the role of PAN in the springtime Northeastern Pacific Troposphere: Results from the PHOBEA campaign, J. Geophys. Res., 106, 28731-28741, 2001.

Lawrence, M. G., Crutzen, P. J., Rasch, P. J., Eaton, B. E., and Mahowald, N. M.: A model for studies of tropospheric photochemistry: description, global distribution, and evaluation, J. Geophys. Res., 104(D12), 26245-26277, 1999.

Liao, H., Adams, P. J., Chung, S. H., Seinfeld, J. H., Mickley, L. J., and Jacob, D. J.: Interactions between tropospheric chemistry and aerosols in a unified general circulation model, J. Geophys. Res., 108(D1), 4001, doi:10.1029/2001JD001260, 2003.

Liao, H. and Seinfeld, J. H.: Global impacts of gas-phase chemistry-aerosol interactions on direct radiative forcing by anthropogenic aerosols and ozone, J. Geophys. Res., 110, D18208, doi:10.1029/2005JD005907, 2005.

Liao, H., Henze, D. K., Seinfeld, J. H., Wu, S., and Mickley, L. J.: Biogenic secondary organic aerosol over the United States: Comparison of climatological simulations with observations, J. Geophys. Res., 112, D06201, doi:10.1029/2006JD007813, 2007.

Liu, H., Jacob, D. J., Bey, I., and Yantosca, R. M.: Constraints from $210 \mathrm{~Pb}$ and $7 \mathrm{Be}$ on wet deposition and transport in a global threedimensional chemical tracer model driven by assimilated meteorological fields, J. Geophys. Res., 106(D11), 12109-12128, 2001.

Liu, Y., Gibson, J. H., Cain, J. P., Wang, H., Grassian, V. H., and Laskin, A.: Kinetics of Heterogeneous Reaction of CaCO3 Particles with Gaseous HNO3 over a Wide Range of Humidity, J. Phys. Chem. A, 112, 1561-1571, 2008.

McNaughton, C. S., Clarke, A. D., Kapustin, V., Shinozuka, Y., Howell, S. G., Anderson, B. E., Winstead, E., Dibb, J., Scheuer, E., Cohen, R. C., Wooldridge, P., Perring, A., Huey, L. G., Kim, S., Jimenez, J. L., Dunlea, E. J., DeCarlo, P. F., Wennberg, P. O., Crounse, J. D., Weinheimer, A. J., and Flocke, F.: Observations of heterogeneous reactions between Asian pollution and mineral dust over the Eastern North Pacific during INTEX-B, Atmos. Chem. Phys., 9, 8283-8308, 2009, http://www.atmos-chem-phys.net/9/8283/2009/.

Martin, R. V., Jacob, D. J., Yantosca, R. M., Chin, M., and Ginoux, P.: Global and regional decreases in tropospheric oxidants from photochemical effects of aerosols. J. Geophys. Res. 108(D3), 4097, doi:10.1029/2002JD002622, 2003.

Maxwell-Meier, K., Weber, R., Song, C., Orsini, D., Ma, Y., Carmichael, G. R., and Streets, D. G.: Inorganic composition of fine particles in mixed mineral dust-pollution plumes observed from airborne measurements during ACE-Asia, J. Geophys. Res., 109, D19S07, doi:10.1029/2003JD004464, 2004.

Meskhidze, N., Chameides, W. L., and Nenes, A.: Dust and pollution: A recipe for enhanced ocean fertilization?, J. Geophys. Res., 110, D03301, doi:10.1029/2004JD005082, 2005.

Mogili, P. K., Kleiber, P. D., Young, M. A., and Grassian, V. H.: Heterogeneous Uptake of Ozone on Reactive Components of Mineral Dust Aerosol: An Environmental Aerosol Reaction Chamber Study, J. Phys. Chem. A, 110(51), 13799-13807, 2006.

Nam, J., Wang, Y., Luo, C., and Chu, D. A.: Trans-Pacific transport of Asian dust and CO: accumulation of biomass burning $\mathrm{CO}$ in the subtropics and dipole structure of transport, Atmos. Chem. Phys. Discuss., 9, 12899-12926, 2009,

http://www.atmos-chem-phys-discuss.net/9/12899/2009/.

Olivier, J. G. J., Berdowski, J. J. M., Peters, J. A. H. W, Bakker, J., Visschedijk, A. J. H., and Bloos, J. P. J.: Applications of EDGAR. Including a description of EDGAR 3.2: reference database with trend data for 1970-1995, RIVM, Bilthoven, RIVM report 773301 001/NRP report 410200 051, 2001.

Ooki, A. and Uematsu, M.: Chemical interactions between mineral dust particles and acid gases during Asian dust events, J. Geophys. Res., 110, D03201, doi:10.1029/2004JD004737, 2005.

Park, R. J., Jacob, D. J., Chin, M., and Martin, R. V.: Sources of carbonaceous aerosols over the United States and implications for natural visibility, J. Geophys. Res., 108(D12), 4355, doi:10.1029/2002JD003190, 2003.

Park, R. J., Jacob, D. J., Field, B. D., Yantosca, R. M., and Chin, M.: Natural and transboundary pollution influences on sulfate-nitrate-ammonium aerosols in the United States: Implications for policy. J. Geophys. Res., 109, D15204, doi:10.1029/2003JD004473, 2004.

Park, R. J., Jacob, D. J., Palmer, P. I., et al.: Export efficiency of black carbon aerosol in continental outflow: Global implications, J. Geophys. Res., 110, D11205, doi:10.1029/2004JD005432, 2005.

Park, R. J., Jacob, D. J., Kumar, N., and Yantosca, R. M.: Regional visibility statistics in the United States: Natural and transboundary pollution influences, and implications for the Regional Haze Rule, Atmos. Environ., 40, 5405-5423, 2006.

Preszler Prince, A., Kleiber, P., Grassian, V. H., and Young, M. A.: Heterogeneous interactions of calcite aerosol with sulfur dioxide and sulfur dioxide nitric acid mixtures, Phys. Chem. Chem. Phys., 9, 3432-3439, 2007.

Prospero, J. M., Ginoux, P., Torres, O., Nicholson, S. E., and Gill, T. E.: Environmental characterization of global sources of atmospheric soil dust identified with the NIMBUS 7 total ozone mapping spectrometer (TOMS) absorbing aerosol product, Rev. Geophys., 40(1), 2.1-2.31, 2002.

Rind, D., Chin, M., Feingold, G., Streets, D., Kahn, R. A., Schwartz, S. E., and Yu, H.: Modeling the Effects of Aerosols on Climate, in Atmospheric Aerosol Properties and Climate Im- 
pacts, A Report by the US Climate Change Science Program and the Subcommittee on Global Change Research, edited by: Chin, M., Kahn, R. A., and Schwartz, S. E., National Aeronautics and Space Administration, Washington, DC, USA, 2009.

Rosenfeld, D., Rudich, Y., and Lahav, R.: Desert dust suppressing precipitation: a possible desertification feedback loop, P. Natl. Acad. Sci., 98(11), 5975-5980, 2001.

Scheuer, E., Talbot, R. W., Dibb, J. E., Seid, G. K., DeBell, L., and Lefer, B.: Seasonal distributions of fine aerosol sulfate in the North American Arctic basin during TOPSE, J. Geophys. Res., 108(D4), 8370, doi:10.1029/2001JD001364, 2003.

Shi, Z., Shao, L., Jones, T. P., and Lu, S., Microscopy and mineralogy of airborne particles collected during severe dust storm episodes in Beijing, China, J. Geophys. Res., 110, D01303, doi:10.1029/2004JD005073, 2005.

Shindell, D. T., Faluvegi, G., Bauer, S. E., et al.: Climate response to projected changes in short-lived species under an A1B scenario from 2000-2050 in the GISS climate model, J. Geophys. Res., 112, D20103, doi:10.1029/2007JD008753, 2007.

Singh, H. B., Brune, W. H., Crawford, J. H., Flocke, F., and Jacob, D. J.: Chemistry and transport of pollution over the Gulf of Mexico and the Pacific: spring 2006 INTEX-B campaign overview and first results, Atmos. Chem. Phys., 9, 2301-2318, 2009, http://www.atmos-chem-phys.net/9/2301/2009/.

Solmon, F, Chuang, P. Y., Meskhidze, N., and Chen, Y.: Acidic processing of mineral dust iron by anthropogenic compounds over the North Pacific Ocean, J. Geophys. Res., 114, D02305, doi:10.1029/2008JD010417, 2009.

Song, C. H. and Carmichael, G. R.: A 3-D modeling investigation of the evolution processes of dust and sea salt particles in East Asia, J. Geophys. Res., 106(D16), 18131-18154, 2001a.

Song, C. H. and Carmichael, G. R.: A modeling analysis of partitioning of HNO3 of modulated by alkaline aerosol particles, J. Atmos. Chem., 40, 1-22, $2001 \mathrm{~b}$.

Song, C. H., Maxwell-Meier, K., Weber, R. J., Kapustin, V., and Clarke, A.: Dust composition and mixing state inferred from airborne composition measurements during ACE-Asia C130 flight \#6, Atmos. Environ., 39, 359-369, 2005.

Song, C. H., Kim, C. M., Lee, Y. J., Carmichael, G. R., Lee, B. K., and Lee, D. S.: An evaluation of reaction probabilities of sulfate and nitrate precursors onto East Asian dust particles, J. Geophys. Res., 112, D18206, doi:10.1029/2006JD008092, 2007.

Sullivan, R. C., Guazzotti, S. A., Sodeman, D. A., and Prather, K. A.: Direct observations of the atmospheric processing of Asian mineral dust, Atmos. Chem. Phys., 7, 1213-1236, 2007, http://www.atmos-chem-phys.net/7/1213/2007/.

Szykman, J., Mintz, D., Creilson, J., and Wayland, M.: Impact of April 2001 Asian Dust Event on Particulate Matter Concentrations in the United States, Environmental Protection Agency National Air Quality and Emission Trends Report, S1-S12, 2003.

Tabazadeh, A., Jacobson, M. Z., Singh, H. B., et al.: Nitric acid scavenging by mineral and biomas burning aerosols, Geophys. Res. Lett., 25(22), 4185-4188, 1998.

Thakur, A. N., Singh, H. B., Mariani, P., Chen, Y., Wang, Y., Jacob, D. J., Brasseur, G., Muller, J.-F., and Lawrence, M.: Distribution of reactive nitrogen species in the remote free troposphere: data and model comparisons, Atmos. Environ., 33, 1403-1422, 1999.

Ullerstam, M., Vogt, R., Langer, S., and Ljungstrom, E.: The kinetic and mechanism of $\mathrm{SO}_{2}$ oxidation by $\mathrm{O}_{3}$ on mineral dust, Phys.
Chem. Chem. Phys., 4, 4694-4699, 2002.

Ullerstam, M., Johnson, M. S., Vogt, R., and Ljungstrm, E.: DRIFTS and Knudsen cell study of the heterogeneous reactivity of $\mathrm{SO}_{2}$ and $\mathrm{NO}_{2}$ on mineral dust, Atmos. Chem. Phys., 3, 2043-2051, 2003, http://www.atmos-chem-phys.net/3/2043/2003/.

Umann, B., Arnold, F., Schaal, C., Hanke, M., Uecker, J., Aufmhoff, H., Balkanski, Y., and Van Dingenen, R.: Interaction of mineral dust with gas phase nitric acid and sulfur dioxide during the MINATROC II field campaign: First estimate of the uptake coefficient $\gamma\left(\mathrm{HNO}_{3}\right)$ from atmospheric data, J. Geophys. Res., 110, D22306, doi:10.1029/2005JD005906, 2005.

Underwood, G. M., Song, C. H., Phadnis, M., Carmichael, G. R., and Grassian, V. H.: Heterogeneous reactions of $\mathrm{NO}_{2}$ and $\mathrm{HNO}_{3}$ on oxides and mineral dust: A combined laboratory and modeling study, J. Geophys. Res., 106(D16), 18055-18066, 2001.

Usher, C. R., Al-Hosney, H., Carlos-Cuellar, S., and Grassian, V. H.: A laboratory study of the heterogeneous uptake and oxidation of sulfur dioxide on mineral dust particles, J. Geophys. Res., 107(D23), 4713, doi:10.1029/2002JD002051, 2002.

Usher, C. R., Michel, A. E., and Grassian, V. H.: Reactions on mineral dust, Chem. Rev., 103, 4883-4939, 2003.

van Donkelaar, A., Martin, R. V., Leaitch, W. R., Macdonald, A. M., Walker, T. W., Streets, D. G., Zhang, Q., Dunlea, E. J., Jimenez, J. L., Dibb, J. E., Huey, L. G., Weber, R., and Andreae, M. O.: Analysis of aircraft and satellite measurements from the Intercontinental Chemical Transport Experiment (INTEX-B) to quantify long-range transport of East Asian sulfur to Canada, Atmos. Chem. Phys., 8, 2999-3014, 2008,

http://www.atmos-chem-phys.net/8/2999/2008/.

Vlasenko, A., Sjogren, S., Weingartner, E., Stemmler, K., Gäggeler, H. W., and Ammann, M.: Effect of humidity on nitric acid uptake to mineral dust aerosol particles, Atmos. Chem. Phys., 6, 21472160, 2006,

http://www.atmos-chem-phys.net/6/2147/2006/.

Vlasenko, A., Huthwelker, T., Gäggeler, H. W., and Amann, M.: Kinetics of the heterogeneous reaction of nitric acid with mineral dust particles: an aerosol flow tube study, Phys. Chem. Chem. Phys., 11, 7921-7930, doi:10.1039/b904290n, 2009.

Wang, Y. Jacob, D. J., and Logan, J. A.: Global simulation of tropospheric O3- $\mathrm{NO}_{\mathrm{x}}$-hydrocarbon chemistry, 1 model formulation, $\mathrm{J}$. Geophys. Res. 103(D9), 10713-10725, 1998.

Wesely, M. L.: Parameterization of surface resistance to gaseous dry deposition in regional-scale numerical models, Atmos. Environ., 23, 1293-1304, 1989.

Zender, C. S., Bian, H., and Newman, D.: Mineral Dust Entrainment And Deposition (DEAD) model: Description and 1990s dust climatology, J. Geophys. Res., 108(D14), 4416, doi:10.1029/2002JD002775, 2003.

Zhang, L., Gong, S., Padro, J., and Barrie, L.: A size-segregated particle dry deposition scheme for an atmospheric aerosol module, Atmos. Environ., 35, 549-560, 2001.

Zhang, D. Z. and Iwasaka, Y., Nitrate and sulfate in individual Asian dust-storm particles in Beijing, China in spring of 1995 and 1996, Atmos. Environ., 33, 3213-3223, 1999.

Zhang, L., Jacob, D. J., Boersma, K. F., Jaffe, D. A., Olson, J. R., Bowman, K. W., Worden, J. R., Thompson, A. M., Avery, M. A., Cohen, R. C., Dibb, J. E., Flock, F. M., Fuelberg, H. E., Huey, L. G., McMillan, W. W., Singh, H. B., and Weinheimer, 
A. J.: Transpacific transport of ozone pollution and the effect of recent Asian emission increases on air quality in North America: an integrated analysis using satellite, aircraft, ozonesonde, and surface observations, Atmos. Chem. Phys., 8, 6117-6136, 2008, http://www.atmos-chem-phys.net/8/6117/2008/.
Zhang, Q., Streets, D. G., Carmichael, G. R., He, K. B., Huo, H., Kannari, A., Klimont, Z., Park, I. S., Reddy, S., Fu, J. S., Chen, D., Duan, L., Lei, Y., Wang, L. T., and Yao, Z. L.: Asian emissions in 2006 for the NASA INTEX-B mission, Atmos. Chem. Phys., 9, 5131-5153, 2009,

http://www.atmos-chem-phys.net/9/5131/2009/. 